Таким чином, пріоритети якісної міжкультурної фахової освіти майбутніх фахівців-міжнародників грунтуються на трьох засадах: наукове дослідження, професійне навчання та практична підготовкастажування, що передбачає розширення переліку міжнародних дисциплін, застосування найсучасніших технологій, вивчення декількох іноземних мов, активізацію діяльності перекладацьких студій, організацію виробничих практик на базі діючих міжнародних організацій, оплачувані стажування.

\title{
Література:
}

1. Василишина Н.М. Теоретичні і методичні засади крос-культурної освіти майбутніх магістрів сфери туризму України та Туреччини в умовах євроінтеграційних процесів: Дис. ... доктора педагогічних наук /13.00.04. Національний авіаційний університет, Київ, 2021. 655 с.

2. Третько В.В. Формування професійної компетентності фахівців міжнародних відносин. Збірник наукових праць НАДПСУ. Серія: педагогічні та психологічні науки. 2015. № 1(74). С.279-292.

DOI https://doi.org/10.30525/978-9934-26-114-5-67

\section{ПЕРЕХІД ДО БАГАТОРІВНЕВОЇ ВИЩОЇ ОСВІТИ В УМОВАХ ДИСТАНЦІЙНОГО НАВЧАННЯ}

\author{
Ладанівська І. Ю. \\ асистент кафедри іноземних мов для природничих факультетів \\ факультету іноземних мов \\ Львівський національний університет імені Івана Франка \\ м. Львів, Украӥна
}

Багаторівнева система вищої освіти зумовлена необхідністю нашого суспільства, адже воно спрямоване на те, щоб освіта стала доступною для всього населення. Освіта $\epsilon$ надвичайно важливим інструментом сьогодення, кожен може вибрати освіту в залежності від своїх здібностей, нахилу до тієї чи іншої спеціалізації, можливості та бажання. Конституція України регламентує, що кожен має право на освіту. Повна загальна середня освіта є обов'язковою. Держава забезпечує доступність і безоплатність дошкільної, повної загальної середньої, професійно-технічної, вищої освіти в державних і комунальних навчальних закладах; розвиток дошкільної, повної загальної середньої, 
позашкільної, професійно-технічної, вищої і післядипломної освіти, різних форм навчання; надання державних стипендій та пільг учням i студентам. Громадяни мають право безоплатно здобути вищу освіту в державних i комунальних навчальних закладах на конкурсній основі [2].

Вітчизняний та зарубіжний досвід показує тенденцію поширення багаторівневої освіти та розширення вимог до всіх спеціальностей, які нам диктує суспільство та технології. Тому багаторівневість у педагогічній освіті $€$ необхідністю, спричиненою як зовнішніми (ієрархічність, відкритість, сумісність, економічність), так і внутрішніми (цінність, динамічність, цілісність, результативність) критеріями. [1]

Найважливішим завданням для кожного студента, який прагне бути фахівцем у своїй галузі, враховуючи стрімкий розвиток нових технологій, є постійне підвищення рівня теоретичних та практичних знань студента. Студент повинен постійно дбати про свій інтелектуальний розвиток, а також слідкувати за новими змінами у своїй галузі, що на даний час є надзвичайно важливим фактором.

Також освіта стає все більш та більш гнучкою, що є дуже важливим та необхідним, адже 2020-2021 роки ввійшли в історію України та в історію всіх країн світу як період кардинального переосмислення розвитку нашої планети, а також змусили нас стати гнучкими. Викладачі та студенти змушені під впливом пандемії COVID-19 перейти на онлайн навчання 3 використанням різноманітних платформ. Спершу всі університети світу зіткнулися із великою кількістю проблем в наданні освіти, як матеріально-технічного, так і організаційного забезпечення, але згодом ці пробеми були вирішені. Дистанційне навчання дозволяє поєднювати роботу 3 навчанням, досягати кар'єрних висот, а також слідувати принципу: «Вік живи - вік учись». Людина повинна навчатися впродовж усього життя, а система освіти має надавати їй такі можливості. Знання у даному разі виступають як основа поведінки і професійної діяльності. I якщо ми хочемо створити сучасну державу, то все населення України повинно вчитися. При цьому, старші покоління мають удосконалюватися, а молодші формуватися в окресленій і затребуваній суспільством іпостасі. [4]

Також не можна не згадати про право вільного переходу з однієї спеціальності на іншу. Ці переходи дозволяють змінювати професію та створюють умови для швидкого реагування вищої школи на питання виробництва, науки і культури. Відтак, багаторівнева освіта підвищує якість вищої освіти на основі гуманітаризації і фундаменталізації освітніх програм, сполучення широкої загальноосвітньої підготовки 
студентів із наступною глибокою спеціалізацією по визначених професійних напрямках. [1] Багаторівнева освіта $є$ яскравим прикладом можливості забезпечити міжнародну співпрацю, чудовою можливістю розширити свій кругозір, запровадити нові методи та підходи.

Провівши аналіз освітньої реформи, можна виділити, що підготовка на численних факультетах здійснюється за єдиним навчальним планом, який передбачає вивчення великої кількості теоретичних вузькоспеціальних дисциплін, більшість із яких не використовуються у професійній діяльності студентів, а також вони не є настільки актуальними і не націлені на розв'язання конкретних задач, які варто розглядати сучасному студенту. Також слід звертати все більшу увагу на розвиток творчих можливостей особистості, активізації глибинних джерел іiі інтелектуального потенціалу. Це надзвичайно складне завдання, а заради його вирішення необхідно об'єднати сили всіх учасників навчально-виховного процесу. Слід звертати увагу на умови чи фактори навчання на різних рівнях, що впливають на навчання студентів загалом.

Структура знань про технологічний педагогічний зміст (The Technological Pedagogical Content Knowledge) та навички оцінювання $\epsilon$ результатами навчання на рівні викладача; організаційні структури, навчальні програми, системи оцінювання та оцінювання шкіл $є$ результатами навчання на рівні викладача; а національна освітня політика, стратегії електронного навчання, вимоги до сертифікації викладача та критерії перевірки в університеті є результатами навчання на системному рівні. Така модель навчання підкреслює важливість педагогічного дизайну (тобто проектування навчального середовища та навчальних взаємодій на різних рівнях) та досягнення цільових результатів [5, с. 116-134]

Враховуючи ситуацію сьогодення, необхідно вдосконалювати, реформувати освіту. Сьогодні найбільш продуктивними і перспективними $є$ технології, що дозволяють організувати навчальний процес 3 урахуванням професійної спрямованості навчання, а також з орієнтацією на особистість учня, його інтереси, можливості та здібності. Саме дистанційні лекції змінюють роль викладача, роблять викладача наставником, який організовує, спрямовує та координує начавльний процес. Такий вид начання змушує викладача удосконалюватись, удосконалювати навчальні матеріали, підвищувати свій творчий потенціал i, зокрема, змушує «іти в ногу з часом». Одночасно студенти мають змогу переглядати всі матеріали, які використовувались на лекціях, переглядати лекції знову, якщо вони щось не зрозуміли. Не можна не сказати і про гнучкість дистанційного навчання, адже 262 
студенти мають змогу переглянути лекцію, якщо вони не були присутні на ній. Підвищення ефективності технологій можливе тільки за умови переважання на всіх етапах навчального процесу творчої, пошукової діяльності студентів, де відбуватиметься відхід від жорсткої уніфікації, однаковості цілей, змісту, методів, засобів і організаційних форм навчання, до розвитку та виховання індивідуалізації та диференціації самої навчально-пізнавальної діяльності. [3] Лише у цьому випадку, ми матимемо освічену націю, здатну мислити та творити нову історію.

\title{
Література:
}

1. Власенко С.П. Особливості становлення сучасної багаторівневої освіти вчителів початкових класів. - 2002 [Електронний ресурс]. Режим доступу : http://enpuir.npu.edu.ua/bitstream/handle/123456789/ 7893/Vlasenko.pdf?sequence=1\&isAllowed=y

2. Конституція України. Закон України від 28. 06. 1996 № 254к/96ВР // Відомості Верховної Ради України. -1996. - Режим доступу: https://zakon.rada.gov.ua/laws/show/254к/96-вр\#Text

3. Кравцова I. А. Особливості багаторівневої системи освіти в сучасному вузі і ідеї болонського процесу. - Криворізький державний педагогічний університет. - м Кривий Ріг. - 2015.

4. Таланчук Петро. Сформуй осердя свого щастя / П.М. Таланчук К. : Університет «Україна», 2014. - 79 с.

5. Law Nancy. Technology-enhanced innovative pedagogy: The challenge.- University of Hong Kong. Understanding innovative pedagogies: key themes to analyze new approaches to teaching and learning. - 2018. P. 116-134

DOI https://doi.org/10.30525/978-9934-26-114-5-68

\section{МАГІСТЕРСЬКА ПІДГОТОВКА ПЕРЕКЛАДАЧІВ В УНІВЕРСИТЕТАХ БЕЛЬГІї}

\author{
Чернова Ю. А. \\ викладач кафедри теорї та практики перекладу \\ Одеський національний університет імені I. І. Мечникова \\ м. Одеса, Україна
}

В умовах інтеграції України в європейський освітній простір зросла необхідність у фахівцях з іноземної мови, що зможуть забезпечити 